\title{
THE POSSIBILITY OF HYDRAULIC DISPENSER APPLICATION IN THE FEED MIXTURE FACTORIES
}

\author{
Darko Kiš, Sonja Vila, Sunčica Guberac, Vedran Orkić, Vlado Guberac \\ Faculty of Agriculture in Osijek, University of J. J. Strossmayer in Osijek, \\ V. Preloga 1, 31000 Osijek, Croatia \\ dkis@pfos.hr
}

\begin{abstract}
The aim of this study was to show the possibility of application of a hydraulic motor powered dispenser in the existing feed mixture factories where dispensers are powered by electric motors. The study was conducted in a feed mixture factory in Croatia on samples of compound feed for pigs weighing up to 15 and 25 kilograms. The study determined the relative error as a means for comparing the calculations of the deviation between the hydraulic dispenser and the dispenser powered by standard electric motor. The research results indicate that in the 30 repeats of making pig mixtures none of the weighed components matched the given recipe. The hydraulic dispenser showed greater precision in adding the fish meal, extruded soy bean and soy bean meal in the mixture compared to the dispenser powered by electromotor.
\end{abstract}

Key words: dispenser; hydraulic dispenser; recipes; feed mixtures

\section{МОЖНОСТ ЗА ПРИМЕНА НА ХИДРАУЛИЧЕН ДИСПЕНЗЕР ВО ФАБРИКИТЕ ЗА ДОБИТОЧНА ХРАНА}

Целта на оваа студија беше да се покаже на можноста за примена на диспензер со хидроуличен мотор во постојните фабрики за добиточна храна, каде што диспензерите ги движат електричните мотори. Студијата беше спроведена во фабрика за добиточна храна во Хрватска на примероци од крмни смески за свињи со тежина од 15 до 25 килограми. Студијата ја утврди релативната грешка како средство за споредување на пресметките за девијација помеѓу хидрауличниот диспензер и диспензерот со стандарден електричен погон. Резултатите од истражувањето покажаа дека во 30-те повторувања на правење смески за свињи ниту една од измерените компоненти не одговарала на дадениот рецепт. Хидрауличниот распрснувач покажа поголема прецизност во додавањето на рибино брашно, екструдирана соја и соино ќспе во смеската во споредба со диспензерот со електромотор.

Клучни зборови: диспензер; хидрауличен диспензер; рецепти; крмни смески

\section{INTRODUCTION}

The process of making a feed mixture does not involve creating a new product. Certain raw materials are cut fine and mixed in ratios, thus producing a mixture where each ingredient keeps its own properties (Katić, 1997). According to recipes, raw materials are added and mixed in specific ratios. To determine the quality of the final product it had to be made exactly according to the recipe. In order to achieve that one of the key devices are adders
(Krička, 1988; Kiš and Rak, 1998). To achieve the required aim adders would have to be reconstructed. Research conducted by Krička (1992) and VojtaDuda (1995) suggests reconstruction of existing livestock feed production plants in the Republic of Croatia. According to their research, corn should be added directly into the mixer, while other ingredients should previously be weighed and mixed into so called "super". "Supper" and corn are mixed in 1:1 ration in a different mixer with bigger capacity. "Super" is then transported to a separate chamber 
placed above a control scale, which was used in the process of filling the continuous mixer. Corn is added to the mixer directly by a double auger device, which operation is controlled by the scale. This kind of ingredient adding increased the capacity of the plant.

In the world today oil hydraulics is increasingly applied with various kinds of transmission and rotation drives, especially in cases of a greater need of a bigger force and rotation momentum (Mc Ellhiney, 1992).

By applying proportional hydraulics, benefits of hydraulics in producing and transmitting great powers have recently been increasing. Proportional hydraulics allow a very simple regulation of physical factors (force, momentum, speed of movement, and rotation). Plant management optimization, as well as maximum productivity and precision, was made possible by application of proportional hydraulics. Proportional hydraulics aided by the latest electronics can very efficiently decrease starting strain, as well as inertial movements that follow the operation shut down, which pose a significant problem in all mechanically powered systems. According to Vojta-Duda (1997) increase of the plant operation precision is affected by the application of proportional hydraulics in systems for precision adding, together with control of feed mixture ingredients weighing. Therefore, the aim of this paper is to determine differences in precision of adding between an adder powered by an electrical motor and hydraulic adders which are proposed as alternative way of ingredient adding in existing production plants.

\section{MATERIAL AND METHODS:}

Researches on differences in adding ingredients into livestock feed mixtures lasted and were conducted in livestock feed production plants in the Republic of Croatia. Ingredient added by means of adders powered by electrical motors was compared with an experimental hydraulic facility constructed for the purpose of the research. Thirty repetitions were conducted for every ingredient specified by the recipe in every single feed mixture and production plant.

Production process is semi-automated in plant "A". Both auger and circular adders are used in the process of adding. The scale is a hopper and horizontal one with a ribbon mixer with the same capacity. In these plants the command panel operator manually controls the recipe for feed mixture by means of potentiometer.

An experimental facility for adding ingredients have hydraulic adders, so called KVK-adder (Katić Vojta-Kanajet) constructed for the purpose of the research. There is a 0.8 -meter-wide passage between the chambers. The passage reaches the cells manually filled with various ingredients. A control microprocessor, KVK-adder, with adequate function and memory capacity, is used for generating the electronic control-signal, as well as for accomplishment of other tasks present at the management of batching and mixing process and the whole process of livestock feed production. The function of the $\mathrm{KVK}$-adder is to receive the measure signal for added mass through an electronic measuring cell that guarantees high accuracy to the whole system of livestock feed production. Since many mixers today are equipped with mechanical scales, adders are also adjusted for receiving a signal from a mechanical scale potentiometer.

All results have been statistically processed, and the error was calculated by means of the relative error method. Based on that, a reconstructtion of livestock feed production plants was suggested.

\section{RESULTS AND DISCUSSION}

Table 1 shows the individual and average results of weighing components for fattening of pigs up to $25 \mathrm{~kg}$ in TKS "A". Corn was added through two adders. On the first adder, at 31 corn weights, the added corn has a mean value of $1203,80 \mathrm{~kg}$, and the default value is $1200 \mathrm{~kg}$. The difference in these values is small. However, as the minimum weigh is $1195 \mathrm{~kg}$, and the maximum weigh is $1204 \mathrm{~kg}$, the variation range is $9 \mathrm{~kg}$. On the second adder, at 31 corn weights, the added corn has a mean value of $144,19 \mathrm{~kg}$, which is more than the default value of $132 \mathrm{~kg}$, and the range of variation between the minimum and maximum weight is $4 \mathrm{~kg}$. When adding livestock flour, at 31 weights, added livestock flour has a mean weight value of $147.68 \mathrm{~kg}$, which is less than the $150 \mathrm{~kg}$ of default value, and the range of variation between the minimum and maximum weight is $9 \mathrm{~kg}$. Out of a total of 31 soybean meal weights, only 3 are accurate, i.e. correspond to the default value. When adding extruded soybean, at 31 weights, the added soy has a mean value of 254.50 $\mathrm{kg}$ of weights, which is less than the default value, $260 \mathrm{~kg}$. The variation range between the minimum and maximum weight is $6 \mathrm{~kg}$, and all soybean weights were smaller than the default value. When 
adding fish flour, the added fish flour has a mean value of $68 \mathrm{~kg}$ of weight which is less than the default value of $70 \mathrm{~kg}$. The variation range is $10 \mathrm{~kg}$, which is more than $10 \%$ of the default value, and of 31 of the fish flours weights, 10 are equivalent to the default value.

By the Ordinance on Livestock Feed mixture for fattening of pigs up to $25 \mathrm{~kg}$ should contain at least $18 \%$ of crude protein. By converting the weighted components of the mixture to the protein value we get the protein value of the individual components, which gives a more accurate weighting error. The mean value of crude protein in the mixture is $18.98 \%$, which is less than the amount of protein determined by the Ordinance for Livestock Feed mixture for fattening of pigs up to $25 \mathrm{~kg}$.

Table 2 shows the individual and average results of weighing components for fattening of pigs up to $15 \mathrm{~kg}$ in TKS "A". When adding the corn, at 31 corn weighing, the added corn has a mean value of weights of $1113.48 \mathrm{~kg}$, and the default value is $1110 \mathrm{~kg}$. Out of a total of 31 weights, only 8 are correct, i.e. they correspond to the default value. When adding the extruded soybean, at 31 weights, the added soy has a mean value of $619.90 \mathrm{~kg}$, which is approximately equal to the default value of $620 \mathrm{~kg}$. The range of variation between the minimum and maximum weight is $8 \mathrm{~kg}$, and out of 31 soy weights, 14 correspond to the default value. By the Ordinance on Livestock Feed mixture for fattening of pigs up to $15 \mathrm{~kg}$ should contain at least $20 \%$ of crude proteins. By converting the weighted components of the mixture to the protein value we get the protein value of the individual components, which gives a more accurate weighting error. The mean value of crude protein in the mixture is $19.68 \%$, which is less than the amount of protein determined by the Ordinance for Livestock Feed mixture for fattening of pigs up to $15 \mathrm{~kg}$

Data in Table 3 indicate that corn, extruded soybean and soybean meal were in the experimental facility added in smaller amounts than specified, whereas fishmeal was added in a larger amount than specified. Based on measurement data for ingredient weighing in plant " $A$ ", as well as in the experimental facility "E" by means of the relative error method, errors can be determined in adding certain ingredients into feed mixture for fattening pigs up to $25 \mathrm{~kg}$ and $15 \mathrm{~kg}$.

Table 1

Average weighings of feed mixture ingredients for pigs up to 25 kilograms

\begin{tabular}{lccccccccc}
\hline \hline Plant "A" & Corn & $\begin{array}{c}\text { Meat and } \\
\text { meal } \\
(\mathrm{kg})\end{array}$ & $\begin{array}{c}\text { Extruded } \\
\text { soybean } \\
(\mathrm{kg})\end{array}$ & $\begin{array}{c}\text { Fish } \\
\text { meal } \\
(\mathrm{kg})\end{array}$ & $\begin{array}{c}\text { Sunflower } \\
(\mathrm{kg})\end{array}$ & $\begin{array}{c}\text { Corn } \\
\text { fragments } \\
(\mathrm{kg})\end{array}$ & $\begin{array}{c}\text { Other } \\
\text { ingredients } \\
(\mathrm{kg})\end{array}$ & $\begin{array}{c}\text { Total } \\
(\mathrm{kg})\end{array}$ & $\begin{array}{c}\text { Time } \\
(\mathrm{min})\end{array}$ \\
\hline Set by the recipe & 1200 & 150 & 260 & 70 & 120 & 132 & 68 & 2000 & 5 \\
$\mathrm{X}$ & 1203.80 & 147.68 & 254.50 & 68 & 121.88 & 144.19 & 68 & 2005.03 & $4^{\prime} 56^{\prime \prime}$ \\
$\mathrm{Xmin}$ & 1195 & 143 & 250 & 64 & 118 & 142 & 68 & 2004 & $4^{\prime} 46^{\prime \prime}$ \\
Xmax & 1204 & 152 & 256 & 74 & 125 & 146 & 68 & 2006 & $5^{\prime} 10^{\prime \prime}$ \\
$\sigma$ & 1.88 & 2.43 & 2.01 & 2 & 2.06 & 1.49 & 0 & 1.016 & 0.1554 \\
c.v. & 0.161 & 1.644 & 0.788 & 2.941 & 1.69 & 1.035 & 0 & 0.050 & 3.1556 \\
\hline \hline
\end{tabular}

Table 2

Average ingredient weighings for feed mixture for pigs up to 15 kilograms

\begin{tabular}{lcccccc}
\hline \hline Plant "A" & $\begin{array}{c}\text { Corn } \\
(\mathrm{kg})\end{array}$ & $\begin{array}{c}\text { Extruded } \\
\text { soybean }(\mathrm{kg})\end{array}$ & $\begin{array}{c}\text { Fish meal } \\
(\mathrm{kg})\end{array}$ & $\begin{array}{c}\text { Other ingredients } \\
(\mathrm{kg})\end{array}$ & $\begin{array}{c}\text { Total } \\
(\mathrm{kg})\end{array}$ & $\begin{array}{c}\text { Time } \\
(\mathrm{min})\end{array}$ \\
\hline Set by the recipe & 1110 & 620 & 90 & 180 & 2000 & 5 \\
$\mathrm{X}$ & 1113.48 & 619.90 & 89.35 & 180 & 2002.80 & $4^{\prime} 50^{\prime \prime}$ \\
$X_{\min }$ & 1111 & 616 & 86 & 180 & 2000 & $4^{\prime} 37^{\prime \prime}$ \\
$X_{\max }$ & 1116 & 624 & 92 & 180 & 2004 & $4^{\prime} 56^{\prime \prime}$ \\
$\Sigma$ & 1.12 & 1.619 & 1.81 & 0 & 1.4926 & 0.1114 \\
c.v. & 0.101 & 0.2609 & 2.03 & 0 & 0.0745 & 2.3064 \\
\hline \hline
\end{tabular}


Table 3

Average ingredient weighings for feed mixture in the experimental facility " $E$ "

\begin{tabular}{lcccc}
\hline \hline Experimental facility & $\begin{array}{c}\text { Corn } \\
(\mathrm{g})\end{array}$ & $\begin{array}{c}\text { Extruded soybean } \\
(\mathrm{g})\end{array}$ & $\begin{array}{c}\text { Fish meal } \\
(\mathrm{g})\end{array}$ & $\begin{array}{c}\text { Soybean meal } \\
(\mathrm{g})\end{array}$ \\
\hline Set by the recipe & 800 & 1200 & 800 & 1200 \\
$\mathrm{X}$ & 795.807 & 1193.935 & 801.064 & 1195.387 \\
$\mathrm{Xmin}$ & 791 & 1187 & 795 & 1193 \\
Xmax & 798 & 1200 & 807 & 1198 \\
$\Sigma$ & 1.796652 & 3.53963 & 4.00778 & 1.542237 \\
c.v. & 0.225 & 0.296 & 0.50 & 0.129016 \\
\hline \hline
\end{tabular}

Relative error in adding fish meal into feed mixture for pigs up to $25 \mathrm{~kg}$ was the largest in livestock feed production plant "A", amounting to $30.41 \%$, whereas the smallest was in the experimental facility, being $4.556 \%$. Relative error in adding extruded soybean was the biggest in plant "A" $-25.06 \%$, and the smallest in the experimental facility, being $5.053 \%$.

Relative error for adding fishmeal into the feed mixture for pigs up to $15 \mathrm{~kg}$ was the biggest in plant "A", amounting to $22.744 \%$. It was the smallest in the experimental facility $-4.56 \%$. Relative error in adding soybean meal was also the biggest in plant "A", amounting to $22.56 \%$ o and the smallest in the experimental facility $-3.844 \%$ o. The biggest relative error for extruded soybean was $20.80 \%$ o.

\section{CONCLUSION}

The following can be concluded based on the results of the research:

1. There is a difference among the observed production plants in number of feed mixture ingredients being added into feed mixtures for pigs up to 15 kilograms and into feed mixture for pigs up to 25 kilograms alike.

2. Based on the research results it can be concluded that not one weighings corresponded to the ones specified in the recipe, that being the case in all of the production plants.

3. Using the hydraulic adder instead of an adder with an electrical motor will result in a higher precision in adding fine grain or coarse grained ingredients. In adding coarse-grained ingredients, the existing adders, i.e. adders powered by electric motors, showed a higher accuracy than hydraulic adders, which means that they do not have to be replaced by hydraulic adders in the existing plants.

\section{REFERENCES:}

[1] Katić, Z:: Malene miješaone krmnih smjesa - da ili ne? Krmiva, 39, 4, 199-207 (1997).

[2] Kerep, Nadica: Homogenost krmnih smjesa i predsmjesa miješanih u horizontalnim i vertikalnim mješalicama, Krmiva, 28, 12, 287-298 (1986).

[3] Kiš, D., Rak, A.: Tehnološki značaj uređaja za dodavanje i odvagu krmnih smjesa. Zbornik radova XIV Međunarodnog savjetovanja tehnologa sušenja i skladištenja ''Zrnko 98', Stubičke Toplice, 1998, 168-180..

[4] Kiš, D., Emert, R., Jurić, T., Knežević, D.: Feeders with hydromotors in fodder factories, 14th International DAAM Symposium, Katalinić, Branko (ur.)., Beč, Austrija : DAAM International, 2003, 225-226.

[5] Kiš, D., Jurić, T., Voća, N., Ćurić, D., Mandurić, M.: Reconstruction of existing livestock feed production plants by adding a hydraulic adder, Poljoprivreda (Osijek). 13, 1, 218-221 (2007).

[6] Kiš, D., Stoić, A., Hunjet, A., Jurić, T., Dikonjić, Lj: Hsdraulic adder in livestock feed production, A Magyar Tudomány Ünnepe alkalmából rendezett tudományos konferencia kiadványa Bács-Kiskun Megyei Tudományos Fórum : AGTEDU 2008: Proceedings, Belina, Károly; Klebniczki, József; Csabai, Sarolta; Pető, Judit (ur.)., Kecskemet: Kecskeméti Föiskola Kecskemét College, 2008, 116-122.

[7] Krička, T.: Analiza rada sustava za doziranje komponenata u pet tvornica stočne hrane. II Naučni skup „Industrijski sistemi u agrokompleksu”, Dubrovnik, 1988, 123-134,

[8] Krička, T.: Analiza povećanja kapaciteta u TKS dodavanjem kukuruza na kraju tehnološkog procesa. Zbornik radova VIII Meunarodnog savjetovanja tehnologa sušenja $i$ skladištenja, Stubičke Toplice, 1992, 146-164.

[9] Mc Ellhiney, R.: Inovationsin mixed feed manufacturing technology, The First Tukey International Congress of Mixed Feed, Atlanta, 1992, 75-86.

[10] Vojta-Duda, Lj., Krička, T.: Tehnološki i tehnički zahthevi na uređaje koji vode proizvodnju krmnih smjesa. Krmiva, 37, 2, 69-76 (1995). 